\title{
Self-Portrait of a Narcissist
}

\author{
Pierre-Étienne Will
}

This essay deals with an autobiography written sometime around 1680 and of a quite unique nature. Autobiography is an old genre in Chinese literature, going back to the postface and "letter to Ren An" in Sima Qian's Shiji. These two texts are quite candid and emotional statements, just as would be, much later, the most interesting among first-person accounts written during the transition from Ming to Qing. But in between, writing about oneself was largely dominated by the conventions of the biographical genre, also a creation of Sima Qian, pursued in the entire series of standard histories and in their innumerable avatars and byproducts. Without entering into details, it should be enough to recall that in the Chinese tradition the biography of an individual aimed to situate him (or very occasionally, her) within an ideal-typical "role": a model official, say, or a littérateur, an artist, a scholar, a paragon of filial piety or female chastity, etc.; or more rarely, a negative type, such as cruel official, sycophant, rebel, and a few others. As a result of this classificatory bent, the subject of a conventional Chinese biography is always a one-dimensional being deprived of depth and complexity: a character rather than a person with his or her individual voice.

It is largely the same with autobiographies, except that, almost by definition, the author/subject of an autobiography never presents himself as a negative type. This is only natural if we remember that the main rationale for writing one's life history was to honor one's parents and ancestors, as Liu Zhiji 劉知幾 $(661-721)$ forcefully insisted in the essay on autobiography found in his Shitong 史通—apparently the only theoretical statement in Chinese literature on autobiographical writing: "When one writes about one's own life and discusses one's family's successive generations, assuredly the important thing is to project one's reputation and bring fame to one's parents!" At the same time, Liu Zhiji claims that when writing one's autobiography one must be "truthful,"

1 Shitong, Neipian 內篇, j. 32, “Xuzhuan” 序傳. In his seminal book, The Confucian's Progress: Autobiographical Writings in Traditional China (Princeton: Princeton Univ. Press, 199o), 50-6o, Pei-yi Wu discusses Liu's pronouncements on autobiography and stresses their influence, to the extent that they may have discouraged many people from writing about their own lives. 
or "sincere" (shi 實). In fact, Liu Zhiji's recommendation to reconcile the requirements of ancestral glory and truthfulness is to simply omit whatever may stain one's ancestors' or one's own reputation: "An autobiography that meets the requirements of propriety (or 'duty', $y i$ 義) is when one is able to conceal one's shortcomings, bring out one's qualities, without telling falsehoods - then one gets a truthful (or 'sincere') account." In short, only retain the good, don't mention the bad.

I call this the "respectability requirement," and it has massively dominated both biographical and autobiographical writing in China at all times. But there were exceptions, and it is these that concern us here. We do find first-person writings whose authors tried seriously to look at themselves as autonomous human beings, not just members of a group or class defined by tradition or mere units in the long line formed by their ancestors and their future descendants, to analyze their own behavior, to describe their own emotions and discuss their own uncertainties, and were not afraid of mentioning facts that showed them or their family in a less than ideal light. And as is well known, in China the seventeenth century - the late Ming and, to an certain extent, the first post-conquest decades - was a golden age for such writings, regarded by some as the only authentic sort of autobiography.

One significant factor at work must have been the uneasy conscience of a growing number of people in the face of the enchanted life-style cultivated by the elite, with its combination of extravagance, refinement, and social irresponsibility, and of the contrast it made with the mounting problems that confronted the empire. The late Ming was a time with much selfishness, greediness, and pleasure-seeking among the literate elite, but the concern with the self so typical of the period could also turn into serious consideration of the social and political crises the government seemed increasingly unable to handle, into social activism, and into sometimes agonizing ruminations on the role and attitude of the individual and questions about the family and state institutions that structured everyday life. This is particularly true of the very last years before the 1644 catastrophe and of its aftermath, when more and more people came to feel they were heading straight for total disaster, that they were living the last days not only of the Ming dynasty, but also of a way of life, or indeed of a civilization, to which they were passionately attached. In such circumstances, the usual constraints on writing - the respect of hierarchies, the concern for honorability, even the care for "elegance" - were considerably weakened. 


\section{Wang Jie and His Text}

Wang Jie 汪价, the author to whom this essay is devoted, did experience the violence of the Qing conquest: a native of Jiading 嘉定, one of several Jiangnan cities whose inhabitants were methodically slaughtered in 1645 for having refused to submit to the Manchus, he recounts in his autobiography how when soldiers burst into his residence he barely escaped by jumping over the wall and that the place was looted to the last item. ${ }^{2}$ The text, which Wang wrote in his twilight years sometime in the late 1670s, is entitled Enlarged Account by Himself of the Life of Sannong The Useless (Sannong zhuiren guang zixu 三儂贅 人廣自序). Because of its loose, even disorderly organization and of its disdain for chronology, it is better described as a self-portrait, rather than a formal autobiography. There is a beginning and an ending, though: at the start, Wang's literary education as a child, and at the end, a final listing of his oeuvre, concluding with a few ironic words on the destiny of his future writings (he essentially claims he doesn't care); but in between the few dated life events must be retrieved from a maze of anecdotes and considerations on every kind of subject - though always related to him-the arrangement being essentially by loose association of topics or ideas.

The Sannong zhuiren guang zixu, a rather long text, does not seem to have ever been published separately. It features in juan 20 (and last) of a collection of “trivial sayings” (xiaoshuo 小說) entitled Yuchu xinzhi 虞初新志, first printed in 1700 but with a 1683 preface by its compiler, Zhang Chao 張潮. ${ }^{3}$ The interesting fact, of course, is that Wang's piece should have been published as part not of some collection of "serious" historical/biographical materials, but in a work devoted to "small talk," or "stories" —in other words, of more or less dependable narratives devoid of historical authority and devoted to personalities or events whose defining characteristic is that they are out of the ordinary. Zhang Chao's Yuchu xinzhi contains about 150 entries, mostly biographical sketches of a wide variety of colorful individuals, including a number of women, all of them "extraordinary" ( $y i$ 異) in one way or another. One feature that distinguishes Zhang's work from other similar collections is that, instead of assembling anecdotes from the past culled from previous compilations, it

2 Wang Jie, Sannong zhuiren guang zixu, 4a. On the Jiading massacre and the events that led to it, see the classic study by Jerry Dennerline, The Chia-ting Loyalists: Confucian Leadership and Social Change in Seventeenth-Century China (New Haven: Yale Univ. Press, 1981), in particular chapter 10.

3 There are several other editions of the collection, down to the twentieth century. The pagenumbers in the present essay refer to the original 1700 edition, photo-reproduced in Xuxiu siku quanshu, vol. 1783, and in Siku jinhui shu congkan, 子, vol. 38 . 
collects “modern" (jindai 近代) texts, that is, from authors writing in the early Qing. The one by Wang Jie is by far the longest, and it is the only one written in the first person.

Wang Jie's autobiography is assuredly something out of the ordinary, and as we shall see its author takes pains to show us how "extraordinary" he indeed is. As already stressed by Pei-yi Wu in what to my knowledge is the only existing discussion of Wang's text, ${ }^{4}$ the latter is an extreme, almost outrageous example of the preoccupation with the self that singularizes Ming-Qing transition first-person writings. At the same time, it hardly displays the sort of philosophical doubts, social worries, and political anxieties so common with pre-conquest authors. How far is this a result of Wang's idiosyncrasies, and how far does it reflect the post-conquest times during which the larger part of his adult life unfolded?

\section{Wang Jie: An Outer Biography}

Before attempting to answer these questions, it will be useful to look at what solid information can be found concerning Wang's life and background beyond the curious anecdotes and high-flown claims he himself generously dispenses in his autobiography. In effect, we get no more than in the case of any Chinese literatus without a political, scholarly, or literary career distinguished enough to leave more than a few scattered traces in the written record. The biography of Wang Jie in the 1881 Jiading gazetteer is a four-line entry, saying that Wang, who went by the styles Jieren 介人 and Sannong 三儂, 5 mastered all sorts of literary styles at an early age, became a government student (zhusheng 諸生), travelled widely as a private secretary (muyou 幕友), was invited in 1659 by the governor of Henan to work on the Henan provincial gazetteer, and during the Kangxi period participated in the compilation of the gazetteer of his native Jiading. It also adds, somewhat allusively, that in 1689 one of his sons, Wang Suishi 㴪實, was slandered over some fiscal issues and died in prison. ${ }^{6}$

4 See Wu, The Confucian's Progress, 163-72.

5 The meaning of Sannong is unclear. Though nong 儂 is current for the first-person pronoun in the $\mathrm{Wu}$ dialect, I am not sure that even the ego-obsessed Wang Jie would call himself "Triple-Me."

6 See Jiading xianzhi 嘉定縣志 (1881), 19.20a. The events that led to Wang Suishi's death can be reconstructed based on a few entries in the same gazetteer, in particular $32.21 \mathrm{~b}-22 \mathrm{a}$ on the so-called “ministry fees trial” (bufei yu 部費獄) that happened in 1689—a case of embezzlement that ended with six officials sentenced to death and three hundred Jiading notables, including Wang, stripped of their ranks. Several were later pardoned, but in between Wang had died from ill treatment in prison. 
Evidence scattered in Wang's autobiography and in a few other sources allows us to complement the picture somewhat. Though we do not know Wang's exact dates of birth and death, Wu Pei-yi proposes 1603-1682 with interrogation marks. This would mean that he was in his early thirties-not a very young age - when he became a government student in 1635 (13b). A close examination of the text suggests that his date of birth might be in 1609 or later, however. ${ }^{7}$

A casualty of the fall of Jiading in 1645 that deserves mention here because it is an indicator, however vague, of the family's economic and scholarly standing, was Wang's family library. As Wang Jie recounts it (3b-4a), in 1632 already a fire in their house had destroyed the totality of the Wangs' book collection, which was "several tens of thousands juan" strong. However the Wangs were able to mobilize the wherewithal to reassemble a collection of "several thousand juan": these are the books that were pilfered in 1645 by "mutinied soldiers" who left only a few odd volumes behind them. But more was to come: while Wang Jie had managed to again rebuild a collection of a few hundred juan by doing the rounds of bookstores, in 1651 almost all of them were robbed in circumstances that he does not make altogether clear. And finally, when in 1657 he was arrested for reasons I will discuss later, the few tens of juan he had been able to retrieve were snatched away from his study by the yamen runners who had come to seize him.

Whatever we think of the well-calibrated narrative-after each incident the library is diminished by an order of magnitude - the size of the original collection suggests a comparatively well-to-do literati family with serious scholarly pretensions. Still, if as Wang claims (9a) his father inhabited a modest house with only a few rooms, and with only three bondservants (jiaren 家人), the family must have fallen into harder times at some point. Thus, they had to pawn clothes and rent out part of their residence to be able to rebuild their library in 1632. Wang tells us that in his youth he lived and worked in the cramped cabin of a "half-boat" (banfang 牛舫, one of two boats lashed together), and that when he went to visit rich families in their grand dwellings he did not feel like he belonged to the same world; and he describes his later circumstances as extremely modest.

In 1632, at the time of the fire that destroyed his library, Wang's father, Wang Yunzhen 允貞, was an official: he had just been appointed magistrate of Yuan'an 遠安, in Jingzhou 荆州 prefecture, Hubei, and he had taken his son

7 The latest date in the text is 1678 , and Wang says at one point $(15 \mathrm{~b})$ that he is now seventy years old. Regarding his year of death, there is an indication somewhere that he was still alive around 1684; see Jiading xian xuzhi (1684), 2.30a. 
along. They started rebuilding the collection after their return, which seems to have taken place the very same year: after only three months in the post Wang Yunzhen had been denounced by his superiors for "causing incidents due to his short-temperedness," and had preferred to resign. ${ }^{8}$ This was his first (and apparently last) appointment, which he had eventually received fourteen years after becoming a "tribute student" in 1618, and following a long series of failures at the higher examinations. ${ }^{9}$

In sum, the foregoing suggests that Wang Jie was the scion of a literati family, possibly distinguished in terms of scholarly achievements, apparently of moderate means - though at one point well-to-do enough to build a large library—but without a strong background of examination success and official service. Wang himself never rose above this condition: while apparently enjoying some reputation as a scholar and littérateur, he too failed the provincial examination repeatedly and never became an official. And indeed, Pei-yi Wu's argument in his short essay on Wang's autobiography is that Wang was never able to get over these failures, and that the flamboyant account he gives of his many talents and various adventures must be understood as a compensation for the deep frustration caused by his inability to make it into officialdom.

My own reading is somewhat different; but before discussing this, let me stay for a while with Wang's attempts at passing the provincial examination. Wang says nothing of the attempts at the juren triennial examination he probably made before the fall of the Ming. He speaks of his spectacular despair when the news of the fall of Beijing was received in 1644-crying and stamping his feet, almost wanting to die; but at what must have been the first opportunity offered to him, in 1648, he did attend the provincial examination set up by the new regime (24b). Wang's next dated attempts are in 1651 (19a) and 1654 (22a), and he appears to have pursued the effort, rather incredibly, through 1675 , when he must have been close to seventy years old (13b). In one occurrence where he speaks of his examination-taking without providing a date, he says that he went several times to the capital to pass what was called the Shuntian examination, which candidates hailing from the provinces were allowed to do under certain conditions (2a). (The Shuntian examination was said to be easier than the one in Jiangnan, the most competitive of all; why Wang was able to compete in Beijing is unclear.)

8 See Jiading xianzhi (1673), 11.37b, 16.21a-b. Reportedly, shortly after his arrival in his post Wang arrested and summarily executed a local despot who defied the government, but after they had received his report his superiors were bribed into denouncing him instead.

9 We do not know when Wang Yunzhen died, but there are indications in the autobiography that it happened before the fall of the Ming. 
At this point a word must be said of what Wang calls the "catastrophe" (huo 禍, or nan 難) that befell him in 1657 , which he mentions repeatedly. Referring to the unfortunate series of events that ended with the disappearance of Wang's library, Pei-yi Wu claims that in that year Wang "was implicated in a major criminal case involving hundreds of civil candidates; many of the codefendants were executed. He was acquitted...." Examination scandals did break out in several provinces in 1657. The two major cases occurred in Shuntian (Zhili) and Nanjing (Jiangnan). Both involved gross corruption and favoritism and provoked violent demonstrations when the results were posted. In both cases the successful candidates were re-examined under heavy military surveillance early the following year. The trials that followed ended with the execution or demotion of a number of examiners and other officials involved; a few Shuntian candidates also lost their lives, though the majority of those accused in both cities got off with beatings and exile, or were pardoned. ${ }^{10}$

It is unclear which of the two scandals Pei-yi Wu is alluding to. But what is made clear by a careful examination of the allusions to his ordeal scattered in Wang's text is that in reality it had nothing to do with examinations. Wang was arrested at his home in Jiading, thrown in jail, and apparently threatened with execution. What was the cause? He tells us at one point that he had been imprudent enough to arouse the wrath of people belonging to a political faction, who in turn had started attacking him, all of this ending in what he himself calls a "literary inquisition" (wenzi yu 文字獄) (17b-18a). What the contents of the writings that spurred his arrest may have been Wang does not say. He only deplores his own carelessness: "When I write on current affairs, it is as if I did not know about prisons!"; and when a visitor during his captivity reproaches him for bringing such trouble upon himself by having no idea of what he is writing, he nobly retorts by citing several historical figures (the first is Sima Qian) who were unfairly condemned and yet accomplished great works at great cost to themselves, or were sorry to leave them unfinished when having to submit to execution.

In short, Wang Jie appears to have dabbled in politics during this period of his life, and to have been a victim of his own rashness and propensity to speak too much. And these were dangerous times indeed. Factionalism was rife, and literati—especially southern literati—were prone to take sides or criticize the powers that be, as had been so common in the late Ming. Indeed, the Ming was a close memory and the new regime was still threatened by loyalist forces. In such surroundings it was tempting to crush an enemy by accusing him of

10 For details, see Shang Yanliu 商衍鍙, Qingdai keju kaoshi shulu 清代科舉考試述錄 (Beijing: Sanlian, 1958), 299-304. 
contacts with the loyalists. Whether Wang was victim of such allegations we have no idea, and in fact, apart from mentioning his despair when hearing of the fall of Beijing in 1644, he is totally (and understandably) discreet on his feelings toward the defunct dynasty.

Whatever the case may have been, in the end Wang Jie escaped punishment. In the rather extended development that follows the account of his imprisonment, he gives a list of ten personalities, many of them officials or scholars involved in his life as a student and writer, but also including a courtesan passionately in love with his writings, who "understood him intimately" (zhiji 知已) and from whose benevolence (en 恩) he benefited (18b-20a). The fifth in the list is a certain Li Linzhi 李琳枝, who extracted him from prison: Li, who was examining the students everywhere in the province, including, apparently, Wang in his prison, was deeply impressed by the emotional powers of Wang's paper and concluded his evaluation - if we are to take Wang's words at face value - by emphatically proclaiming that the simple notion of such a genius being threatened with death by a bunch of vulgar people was unbearable.

This was Li Senxian 李森先 (?-166o), who features frequently in the text as "censor Li," and whose position at the time did endow him with the ability to rescue Wang from execution. A Shandong native who had passed the jinshi exam in 1640, he had been recruited by the Qing after they entered Beijing, became a censor in 1645, and served the Qing in this capacity for the next fifteen years, though with periods of disgrace due to enmities caused by his vaunted courage and integrity and by his membership in the so-called southern faction among Chinese officials. ${ }^{11}$ In $1656 \mathrm{Li}$ was dispatched to the Suzhou-Songjiang area as a regional inspector (xun'anyushi 巡按御史), a position that gave him considerable powers to fix whatever problems he chose. There he is said to have earned much popularity by punishing the abuses of the powerful and corrupt, but in the early months of 1657 he was cashiered and called back to the capital for being too lenient with a certain official who had embezzled some tax monies, but had returned them. The date of this incident confirms that his examination of local students, which was part of his duties, and in particular his rescuing of Wang Jie, can only have taken place months before the 1657 provincial examinations were held. Li Senxian was tried and punished in Beijing, but in early 1658 the accusations were rescinded, he was restored to his position, and after some further brushes with the Shunzhi

11 See his detailed biography by Wang Zhengyao 王政堯 in Qingdai renwu zhuangao 清代 人物傳稿, 1st series, vol. 1 (Beijing: Zhonghua shuju, 1984), 132-36. The southern vs. northern faction rivalry in the early Qing was in part a continuation of the one between the Donglin party and the eunuch/northern faction in the late Ming. 
emperor, at the end of the same year he was dispatched to Henan to survey famine conditions. And as it happened, this marked the start of Wang Jie's career as a private secretary.

There are many references in the text to Wang's peripatetic life as a muyou or, more generally, in search of any sort of employment, or just hospitality; but at one point he provides a sort of recapitulation (12a). Though he claims to have travelled half the empire, his activities far from home seem to have mainly taken place in Henan, where he says he spent a total of ten and some years. Sometime in 1658 he entered Li Senxian's cabinet, though it is unclear whether he participated in Li's famine relief work or was, rather, a sort of literary guest. Then he was invited by a certain minister of Rites Xue 薛宗伯, that is, Xue Suoyun 所蘊 (160o-1667), who hailed from Henan, to study in his home at Mengxian 孟縣 together with his elder brothers Wang Zhong 仲 and Wang Qian 蒨. Not long after he was hired by governor Jia Hanfu 賈漢復 to participate in the compilation of the Henan provincial gazetteer, completed in 166o. ${ }^{12}$ Three years later, while he attended the funeral of Xue Suoyun, ${ }^{13}$ Wang was invited by Xue's son Fensheng 奮生 to stay at his home to "discuss things past and present." ${ }^{14}$ Wang says that Xue and his son remained his main benefactors in Henan, and we will see that still in 1678 Xue Fensheng was anxious to promote Wang's career. Following this visit Wang was hired by the prefect of Luoyang, Zhu Canhuang 朱燦煌, to help read examination essays. ${ }^{15}$ The last patron Wang cites by name is Shen Yitang 沈繹堂, that is, Shen Quan 荃 (16241684), who was Henan vice surveillance commissioner between 1656 and 1662, though he is not specific about the kind of work he may have accomplished in his service.

In any event, in the eyes of his local friends and patrons his years in Henan seem to have made Wang Jie a sort of honorary citizen of the province. ${ }^{16}$ And

12 It can be seen at the beginning of this 166o Henan tongzhi 河南通志, a fairly rare edition, that Wang's participation was modest: he was part of a small group of six proofreaders (dingzheng 訂正), all but one being government students, as opposed to the Henan prefects listed as "compilers" (fenji 分輯).

13 Xue died in 1667 , but three years after the compilation of the Henan gazetteer would mean 1663 or thereabout - one example of Wang's casualness with chronology.

Wang calls Xue fils by his style Weigong 衛公, which is not mentioned in any of the documents I have seen on him, and describes him as a "supervising secretary" (huangmen 黃 門, equivalent to jishizhong 給事中), a post that Xue, a 1655 jinshi, held until he retired after getting embroiled in factional politics in Beijing. This is Zhu Mingkui 明魁, who became prefect of Henan fu (Luoyang) in 1661 and seems to have stayed in the post for a decade.

16 For an enumeration of contemporary Henan officials and luminaries to whom Wang Jie is said to have been close, see Zhang Fengtai's 張鳳臺 preface and postface to his 1921 edi- 
it is to Henan that he devoted what appears to be (with his autobiography) his only surviving work, the Zhongzhou zazu 中州雜佮. This is a vast compilation of information and anecdotes culled from other books and arranged under the four headings "Heaven," "Earth," "Man," and "Various Things." It is said to have been compiled in the wake of Wang's work for the Henan provincial gazetteer. In the Qianlong period the Zhongzhou zazu was deemed significant enough to be sent by the Henan governor for inspection by the Siku quanshu commission in Beijing. Though the Siku editors declared it unfit for copying into the "Four Treasuries," they nevertheless inserted an entry in the catalogue of "preserved titles" (сunmu 存目). Their evaluation is not very positive, to say the least: they deplore its confusing organization, unsourced entries, undated anecdotes, and unreliable (that is, unofficial) sources, making the work belong to the xiaoshuo genre; and they conclude with the words "much effort and few results" (ke wei lao er xian gong 可謂勞而鮮功). Still, by being included in the Siku catalogue the Zhongzhou zazu became part of the official bibliography of the empire, and for this reason it is mentioned in various official or semiofficial compilations. ${ }^{17}$

If the Zhongzhou zazu and the Sannong zhuiren guang zixu seem to be Wang Jie's only works preserved today, he wrote many more. He himself enumerates at the end of the autobiography the titles that made up his oeuvre, ten in all, including his Oeuvres complètes, which he says is still in progress; and roughly the same titles (as well as a few others) feature in the bibliographic section of the Jiading gazetteer. ${ }^{18}$ Wang clearly enjoyed some reputation as a man of letters, both in his native Jiading and among his elite friends in Henan. Among the latter was his old acquaintance Xue Fensheng, who according to Wang was eager to help him in his career and in 1678 offered to nominate him for the “Broad Learning and Superior Writing” (boxue hongci 博學宏詞) special examination that was to take place the next year under the personal watch of the Kangxi emperor (22b). As is well known, an unstated aim of the project was to lure scholars of repute who were suspected of loyalty to the former Ming regime into working for the government by participating in the compilation of

tion of Wang's Zhongzhou zazu (on which see below).

17 The 35-juan work described in the Siku notice seems to have been lost. The only text available today is in 21 juan and lacks the part on "Heaven." It was edited and published by Zhang Fengtai in 1921, based on a manuscript found in a Liulichang bookstore in Beijing. See Jiading xianzhi (1673), 24.34a; Jiading xianzhi (1881), 24.14b-15a, 25.12a, 15a, 15b, 26.15a, 22b, 27.15b, 28.9a, 11a, 12a. Wang's writings are often quoted in the Jiading gazetteers. He also seems to have had an interest in administrative matters, a subject completely absent from the autobiography: the statecraft anthology Huangchao jingshi wenbian 皇朝經世 文編 of 1826 features two texts by him (in juan 73 and 9o), one on the postal system and one on judicial amnesties. 
the Ming dynastic history. Several famous scholars who had been nominated managed to excuse themselves from attending. Wang Jie, for his part, did not even want to be nominated. Quoting the letter he wrote Xue to decline, he gives as excuses his arrest in 1657 , his "addiction to books," the fact that he only "deals with trifles," and his lack of talent as an historian: he cannot be regarded as a "famous author," and to speak of "broad learning" about him would be groundless. Such modesty is a far cry from all the bragging in the rest of the autobiography and may imply some loyalist sensibilities on the part of Wang, even if he had tried to pass the Qing examinations. In any case, and assuming the anecdote is authentic, being thought of as eligible to attend the boxue hongci examination suggests that Wang's scholarly stature in the eyes of his friends was quite real.

\section{Wang Jie's Self-Portrait}

The foregoing was an attempt to assemble a factual record of what can be known about Wang Jie's life and works. Surely further details could be discovered here and there, but I doubt they would change much for a profile that does not appear particularly original: after all, in any period there were thousands of impecunious literati, some with talent, learning, and a reputation, who roamed the country in search of employment and protection and every three years tried their luck at the higher examinations. But what makes the autobiography a fascinating document is not this: it is the way Wang describes himself as a unique, indeed an extraordinary personality.

We have seen that for Pei-yi Wu this self-image was a compensation for Wang's deep frustration with his incapacity to succeed at the provincial examination and become eligible for an official career, and as a result for thinking of himself as a nobody, a pathetic failure. Does the text contain any signs that Wang may have experienced such feelings? He does mention his failures, but only after the last one in 1675 does he admit that he felt "distraught" (caolao 愺恅), and tried to "relieve his depression" (shimen 釋悶) by throwing a wild theatrical show with his young servants that was attended by a raucous audience for a full month $(13 \mathrm{~b})$. In a passage where he derides the practitioners of physiognomy who predicted he would become a high minister before age thirty or forty, he adds that now, at age seventy, "the millet is cooked and the time for wild dreams is over" - an allusion to a famous anecdote about the immortal Lü Dongbin. He certainly experienced frustration at some points, but elsewhere he consistently claims that he has no regret. Referring to the several examinations he attended at the capital, he says rather grandly that he had "his 
feet cut by the officials in charge" but that, contrary to his friends who had also been ousted and who were devastated and cried their heart out, he would banquet and have fun, and "be like his old self" (you guwu ye 唒故吾也) (2a). A little later (3a) he enumerates all the misfortunes that befell his friends and classmates who had become officials after the dynastic transition: several perished in Guangdong because of civil war, another died of exhaustion in Guangxi, tribute students were victims of ghosts or bandits on their way to the capital, several had their careers stalled or compromised because they were honest and simple, and many who had passed the jinshi waited "several tens of years" without being called to office. In sum, says Wang, becoming an official confers prestige and nobility on you, but it is at the price of one humiliation after another, of ending up in grave difficulties, or even of losing one's life. He himself did not have the good fortune to succeed, but at least he was able to "happily roam the forests, serenely wearing hide and canvas" to a ripe old age, while "the kingdom of wine and the city of poetry were his long-time apanage." Finally, Wang recounts two dreams in which he was visited by a man dressed in red who cautioned him against writing provocative essays: the first right after his 1657 "catastrophe," where he pledged to limit himself to innocuous writings, and the other following a period during which he had reneged on his promise and been unable to control his ingenuity (jiangxin 匠心) and refrain from his inclination to "hit and stun" (pengqi 砰奇): the man in red tells him that in such conditions he has no hope of passing the examinations; and Wang explains that from then on he "forgot about the imperial court," wine was his constant friend, and he would "look for poets and singers to play in accompaniment" (21b-22a).

Indeed, being a prodigious drinker and an inexhaustible poet is the dominant, one might almost say the structural, motif in Wang's autobiography. While the combination of intoxication and poetry-writing is commonplace in the Chinese literary canon, in the Sannong zhuiren guang zixu it acquires a Rabelaisian quality that may not have many equals. Wang tells us he acquired his fondness for liquor at the early age of five, when he sneaked into the family wine cellar and started sipping from a jar, until the servants found him there, dead drunk. Later, having grown up and "pretending to be from a great family," and as a consequence being invited to multiple banquets, he and a certain Zhu were the only ones able to hold out until dawn, earning the nicknames "AtCockcrow-Zhu" and "At-Dawn-Wang." He also recounts in some detail the only two occurrences in his life when he got drunk after a prolonged binge to the point of losing consciousness (7a-b).

Banquets were of course the occasion par excellence to drink and write verse at the same time, the two activities nourishing each other by way of 
drinking games and other challenges. Several such parties recounted in the text are raucous events described without caring in the least for taste or elegance: the guests drink their fill and beyond, there are shouts of applause and laughter, some get sick or fall asleep, and there are women. One of my favorite among Wang's accounts took place at Mengxian, where Wang was a frequent guest of the Xue family:

The courtesan Little-Red (Xiaohong'er) of Heyang, who was simpleminded but a good drinker, liked to take advantage of that aptitude to overcome people. One day I presented her with a pitcher containing several sheng of wine. Little-Red did not turn it down. She said: "I am good at liquor, you are good at poetry, each time you complete a poem I will drink a cup. Today we will test each other with poetry and wine and decide who is Chu and who is Han!" I hummed verses while Little-Red drank; after we had faced each other drinking several rounds, Little-Red started to look tipsy. Thereupon I chanted a series of poems in a row, and she was not able to stand up to it: she knelt and begged surrender. I let her go to bed, and continued to hum and drink by myself while the guests raised their cups and congratulated me! (23b-24a).

There are other examples of Wang's incredible, almost superhuman, proficiency and ease in versifying. Thus, when he goes to visit censor Li in Henan, Li offers him a booklet containing over a hundred of his poems composed during the year 1656, entitled Bingshen shike 丙申詩刻. Back home Wang orders his servant to warm up some wine for him and gets down to work: at the end of the night he has composed the same number of poems, all set to Li's rhymes, and rushes to the censor's residence to present them. $\mathrm{Li}$ is overwhelmed: it had taken him a year to craft his poems, but now here is someone a hundred times more talented than him! He takes on Wang right away in his cabinet (23b).

But it is not just a question of ease and rapidity. Wang prides himself more than once on the efficacy of his writings - on their ability to convince, to move and captivate an audience. In the most far-fetched instance, it is a tiger that is subdued by Wang's poetry_ - or in this case, his offer of a poem. In 1664, while traveling in the mountains of northwest Zhejiang, Wang and his party encounter a tiger that looks extremely aggressive. Whereas his companions are crouching in panic, Wang approaches the tiger and makes a respectful speech, calling him "Lord of the Mountains" (shanjun 山君) and promising to write a poem for him. The tiger nods three times and goes away. During the night Wang pens a poem in five-syllable verse with sixty rhymes (i.e., 120 lines), which he brings back to the spot where the encounter had taken place and burns, pronouncing 
the wish that the tiger acknowledge it. During that night he dreams of a tiger with a human head that comes to feast him with meat and drink. ${ }^{19}$

In another, less fantastic, instance-one of those ubiquitous banquets, this one at the home of Song Luo 宋恽 (1634-1713) and in the presence of Zhou Lianggong 周亮工 (1612-1672), both important personages and Henan natives-Wang captivates the audience by reading his Blaming the Volcano Guest (Huoshan keqiao 火山客譙), a work written at the time of his 1657 troubles, to such an extent that the guests urge him to go on with his reading until dawn and that the rituals of banqueting are overlooked $(25 \mathrm{~b})$. Other similar examples could be cited, several of which feature in an enumeration of seven occurrences in his life that Wang defines as "occasions for great joy" (kewei dakuaizhe 可爲大快者), each time caused by the recognition of his superior literary abilities by a crowd of distinguished people (24b-26b).

Now, banqueting with one's peers and composing literary works are not highly original subjects in the autobiography (or diary) of a Chinese literatus, even though Wang more often than not endows them with a picaresque or even epic dimension that is rarely found in Chinese first-person writings. Less common is his catholic interest in all sorts of knowledge. And much rarer, perhaps unique, are the freewheeling descriptions he offers of his everyday habits and tastes, the way he speaks of his body and physical experiences, his kindly attitude toward women, his care for the details of material life, and his offhand attitude with money.

The range of specialized disciplines in which Wang claims to have superior knowledge is vast. He says that he has thoroughly studied the doctrines of Buddhism and Taoism, more for their social usefulness - they keep the small folk satisfied with their fate - than for their intrinsic value (15a-b): he does not believe in them and, more generally, several anecdotes stage him as a rational man not to be deluded by sorcerers, soothsayers, or ghosts, and denying the divine retribution of deeds. In a more scholarly vein, he is highly competent in phonetics (14b-15a). ${ }^{20} \mathrm{He}$ has also studied local dialects and composed an important treatise on the subject, the Nongya 儂雅, in 4 juan. ${ }^{21}$ Another area of expertise is music (12b), of which he has a comprehensive knowledge, past and

This is one in a set of three encounters with tigers recounted by Wang (4a-b). See Pei-yi $\mathrm{Wu}, 171$, for a translation of the story. For Wu, it illustrates Wang's intense desire to be recognized as equal to famous officials who drove wild beasts away by the sheer strength of their writing. to the students of a school whose master is so elated that he offers the penniless Wang the money he needs to carry on with his traveling. 
present. He reports that he rectified pitches with the help of a stringed-instrument maker from Jiading, arriving at a tuning of such perfection that "the breaths of the eight winds and twenty-four solar terms all respond to each other"; and he claims that, "extraordinarily," all the high ministers and erudite scholars in the land have adopted it, that its renown has even reached the imperial apartments, and that it is now used to teach the zither.

But where Wang Jie's text is truly out of the ordinary as a self-description, it seems to me, is when it comes to his intimate habits and tastes. The physicality of it is remarkable. Wang discusses, occasionally in great detail, his eyesight (he is short-sighted but his ability to write and read has not been diminished with old age), his hearing (incredibly sharp), his teeth (he lost only two), his hair (in 166o he was dismayed by having to pull out some white hair), his ability to walk long distances and climb mountains (despite "feet lacking strength"), his competence in riding (which as a man of the south, more used to move by boat, he had to learn from scratch when he traveled with censor Li in Henan), and more. He also was trained by an "extraordinary man" (yiren 異人)—clearly a martial arts master - to make his arms as hard as iron, though this was only for the fun, not to make a living as a "brave" ( $5 \mathrm{a}-6 \mathrm{~b}$ for all of the above).

Wang also comments with great precision on his tastes in matter of food and drink, as well as clothes, houses, and more. He mentions tobacco smoking (shiyan 食烟), a recent craze in the region, but criticizes the habit. Though he is short on money most of the time, he makes sure that his hat and outer garment are in perfect condition so as to make him look well-to-do; but otherwise he needs to be sparing with clothes and make them last as long as possible. ${ }^{22}$ As for houses, he hates dampness and darkness and his preference goes to clear and neat rooms in the upper floor, with four windows where he can expose his bare chest to the wind and sun when getting up in the morningprobably not a very common habit of Chinese scholars. Still, his body hygiene must have been limited since he used to dislike taking baths, only discovering the pleasure of it in old age. And in general he says he is strong and in good health, never suffered from a serious illness, never takes any medicine, and whenever he does not feel well treats his discomfort with light wine and a good book - and he gives examples of friends or historical figures who suffered badly or even died for having followed the prescriptions of the ancient medical treatises (7a-10a for the above).

22 He also mentions a robe made of “western cloth” (xiyang bupao 西洋布袍, presumably from Southeast Asia) that his father had made for him when he entered the prefectural school, and which he continued to wear on ceremonial occasions for some thirty years but always refused to wash or re-use as an undergarment. 
Wang discusses sex at some length (10a-11a). He did enjoy it when he was young and strong. ${ }^{23} \mathrm{He}$ even appears to have been a ladies' man, at least if we are to believe his claim that when he visited brothels during his rakish years, the most famous courtesans would offer themselves to him for free, or even give him money, which together with his winnings in gambling dens helped pay for his studies. But at some point he realized that the "lofty talents" (daya 大雅) might not like to hear of this, and stopped once and for all (1a). ${ }^{24}$ And later, at age fifty, he took the more radical decision to definitively abstain from sex, notwithstanding his friends' reproaches and the jokes he faced during banquets.

As a matter of fact, there were no banquets without courtesans, prostitutes, or singing girls whose task it was to take care of the guests, pour them liquor, sing when asked, and more if requested. Wang mentions them often, sometimes by name, and with sympathy. For example, he recounts that, though in the north the attending women are required to show the utmost submission to guests and are treated harshly by the host, he used to make them sit down and ordered the menials to take care of the service, incurring criticism from the northerners because it ruined local customs and the consideration due from the women. The section on sex in the autobiography ends with Taoist-style considerations on the urgent necessity to preserve one's essence (jing 精) and spirit (shen 神), and with a virulent and detailed denunciation of people who attempt to increase their potency with concoctions extracted from wild animals.

And finally, there is Wang's casualness with money: he does not know how to count currency, he is ignorant of the price of local products, he has not been apprised of how to make a profit, and he has no account-book. Money comes and goes and he never has ten taels in store. When he acquires one of these old music instruments (guqi 古器) he loves so passionately, he can be sure he will have to sell it at some point and be depressed by this; and when one day he brings back from Henan some precious antiques he has been offered as a farewell gift, his bondservants laugh at him because they know his treasures will soon have to go. But Wang the spendthrift manages to put his financial irresponsibility under a nobler light when he recounts a family conflict that took place when he was seven years old, during which he haughtily refused the right the local magistrate was awarding him to inherit the property of a deceased

23 He tells us he had two wives, who lived in perfect harmony and gave him two sons each (2a-b).

24 Pei-yi Wu, 167, speaks of the relevant passage as "one of the very few confessions in Chinese autobiography," which I think is an overstatement, but considers that it was not a "genuine" confession because of the lack of "any expression of remorse or sense of guilt." 
uncle to whom he had been appointed heir: he has been like this since childhood, he tells us, "with lofty aspirations but indifferent to riches" (17a-b).

\section{Conclusion}

Is Wang's autobiography a desperate attempt to redeem his many examination failures by singularizing himself from his social peers and making himself admirable as a multi-talented genius and a sort of literary knight-errant? To be sure, he continued for decades trying his luck in the examination hall. But he clearly says that at the time of writing he has become completely comfortable with not being a provincial graduate and not having made an official career. Instead he had a life full of fun, he made friends with a lot of important scholar-officials who admired him, and he enjoyed a reputation as a scholar and, especially, a writer. Reading through the text one senses everywhere his "sunny temperament" (in Pei-yi Wu's apt characterization) and optimism. I tend to think that Wang wrote his self-portrait not as a compensation for some ontological frustration as a failed literatus, but for the sheer pleasure of it-indeed, as a piece that is perfectly appropriate for inclusion in a xiaoshuo collection devoted to "extraordinary" individuals. ${ }^{25}$ No doubt Wang was convinced he was a character out of the ordinary: not just because of his considerable capacity for drinking and fluency in writing verse and prose, which one assumes were shared by many colleagues, but above all for his gargantuan curiosity for every kind of knowledge and experience and his taste for adventure. The impression is that he not only admired himself very much for his abilities, but also found himself and his life interesting, special. Hence his obsession with telling everything and writing it down with a total lack of inhibition. Hence, too, his use of enumerations - of the misfortunes he encountered, of the things he was afraid of, of the people who "understood him intimately," of the "occasions for great joy," and of the things he likes ( $x i$ 喜) or dislikes ( $w u$ 惡). The latter form a list almost poetic in its randomness (16a-b):

I like the sound of a spring, I like the sound of stringed and wind instruments, I like the sound of little boys reciting books in a clear voice, I like the sound of the boatman's oar in the middle of night; I hate the cawing of a flight of crows, I hate the shouting of guards clearing the way, I hate the sound of merchants working on the abacus, I hate the voice of

25 Whether Wang had anything to do with the inclusion of his self-portrait in the Yuchu xinzhi cannot be known. 
women cursing, I hate the voice of men breathing "ah?," I hate the sound of blind women singing ballads and strumming the lute, I hate the sound of scratching the bottom of a pot; I like the sight of the moon at the end of night, I like the sight of snow at dawn, I like the sight of flowers at noon, I like the genuine beauty of women with light make-up, I like the sight of "triple brandy"; I hate the sight of survivor courtesans, I hate the sight of flatterers getting intimate, I hate the sight of grandees who wear masks and disguise themselves. ${ }^{26}$

Here the notion of "truthfulness," or "sincerity" (shi 實), I adduced at the beginning might be invoked. In many late-Ming texts sincerity involves a propensity to analyze oneself, meaning not just moral self-examination but an effort to understand one's own psychology and to interpret one's thoughts and acts. In contrast, Wang Jie's autobiography is more description than introspection, except perhaps for his considerations on old age and the necessity of quieting down and enjoying the settled life of someone who has abandoned all ambitions and no longer possesses the wild energy of his younger years.

The fact is, change is not absent from Wang's account of himself: from the teenager fond of performing magic tricks $(12 \mathrm{a}-13 \mathrm{~b})$ and the young student immersed in gambling and whoring, to the sedate but still sprightly old man who has renounced traveling at the urging of his sons and cultivates his garden, drinks, versifies, and plays chess with his elderly friends, has fun with his servants, and plays with his grandchildren (11a-b); not to mention his renunciation of sex and all the physical manifestations of aging. In this respect at least his self-portrait qualifies as an "autobiography," as an account of life as a process-or a progress, to borrow Pei-yi Wu's term. What most of the authors dealt with in The Confucian's Progress are ruminating over is the changes they went through during their lives, their psychological and spiritual progress, the difficulties and reversals they encountered, and how in the end some of them at least were able to reach a form of enlightenment.

To speak of enlightenment about Wang Jie's progress from riotous young scholar to settled retiree reconciled with his fate would be a gross exaggeration. As I said, his text is description more than reflection; and even though there is some of the latter, it is devoid of profundity. But Wang's descriptions display a form of utmost sincerity, occasionally bordering on self-absorption, both in the material details of his life and activities and in reports of not

26 See Pei-yi Wu, 170, for a somewhat different translation. Wu claims that such likes and dislikes are not very different from those of other seventeenth-century literati and that the list is not a great innovation. 
particularly admirable behavior. The resulting text is a mixture of realism and hyperbole, with much embellishment and, again, a healthy sense of fun.

Finally, and to come back to the question raised at the beginning, Wang's idiosyncrasies and cheerful approach to life are clearly the main reason why his self-portrait is so startlingly different from even the most freewheeling among first-person accounts written during the Ming-Qing transition. Still, does the text reflect the specificities of the early Qing decades that it essentially covers? If it does, it is in a rather limited way. As we saw, what Wang tells of his arrest in 1657 allows a glimpse of the perilous political environment in Jiangnan a little more than a decade after the conquest. At one point in the text there is a brief allusion to the case of a private Ming history that came under censure and in which Wang's friend Zha Jizuo 查繼佐 (1601-1676) - a scholar of some renown who had fought alongside the Southern Ming and who after returning home in 1647 remained suspected of loyalist sentiments by the authorities — was implicated at the beginning of the 166os (6a) ${ }^{27}$ And finally, we can at least suppose that Wang's refusal to be considered for the 1679 boxue hongci examination was partly due to a feeling of guilt toward the ancient regime. Only later would the Qing monarchs systematically and ruthlessly repress the factionalism and overt political criticism that they regarded as a major cause of the fall of the Ming; but even so, Wang Jie is obviously very cautious regarding this kind of thing. In a similar way, it took some time for the Qing to take aim at and discourage the individualistic bent (often inspired by Wang Yangming's brand of neo-Confucianism) and propensity to talk about oneself other than as a public persona that were so characteristic of the late Ming. Indeed, we do find in the second half of the seventeenth century examples of first-person writings revealing the concerns with the self and the tendency to distance oneself from social conventions and conformities often found with authors from the previous generations. ${ }^{28}$ Wang Jie undoubtedly displays no little disregard for the conventional. But where he probably is exceptional is in his deep and completely unrestrained involvement with the minutiae of his physical and material life: a jubilant realism, one might say, that is never found in the writings of his literati peers and that together with his gleeful flights of exaggeration makes his autobiography a most enjoyable exercise in narcissism.

27 On this affair, which cost scores of individuals their lives, see Arthur W. Hummel, ed., Eminent Chinese of the Ching Period (Washington, D.C.: Government Printing Office, 1943), 206

Several examples are analyzed in Wu's Confucian's Progress. 